\title{
Association of $\beta$-Catenin with Fat Accumulation in 3T3-L1 Adipocytes and Human Population
}

\author{
Sungmin Bae ${ }^{1}$, Haeyong Lee ${ }^{1}$, Soo Ahn Chae ${ }^{2}$, Dong-Jin Oh ${ }^{3}$, Sukwon Park ${ }^{4}$ and Yoosik Yoon ${ }^{1}$ * \\ ${ }^{1}$ Department of Microbiology, ${ }^{2}$ Pediatrics, ${ }^{3}$ Internal Medicine, ${ }^{4}$ Radiation Oncology, Chung-Ang University College of Medicine, Seoul 156-756, \\ Korea
}

Received July 25, 2011 /Revised August 26, 2011 /Accepted August 30, 2011

\begin{abstract}
The major function of adipocytes is to store fat in the form of triglycerides. One of the signaling pathways known to affect adipogenesis, i.e. fat formation, is the WNT/ $\beta$-catenin pathway which inhibits the expression and activity of key regulators of adipogenesis. The purpose of this research is to find genes among the WNT/ $\beta$-catenin pathway which regulate adipogenesis by using small interfering (si) RNA and to find the association of single nucleotide polymorphisms (SNPs) of the gene with serum triglyceride levels in the human population. To elucidate the effects of $\beta$-catenin siRNA on adipogenesis key factors, PPARy and $\mathrm{C} / \mathrm{EBPa}$, we performed real-time PCR and western blotting experiments for the analyses of mRNA and protein levels. It was found that the siRNA-mediated knockdown of $\beta$-catenin upregulates adipogenesis key factors. However, upstream regulators of the WNT/ $\beta$ -catenin pathway, such as DVL2 and LRP6, had no significant effects compared to $\beta$-catenin. These results indicate that $\beta$-catenin is a candidate gene for human fat accumulation. In general, serum triglyceride level is a good indicator of fat accumulation in humans. According to statistical analyses of the association between serum triglyceride level and SNPs of $\beta$-catenin, -10,288 C>T SNP (rs7630377) in the promoter region was significantly associated with serum triglyceride levels $(p<0.05)$ in 290 Korean subjects. On the other hand, serum cholesterol levels were not significantly associated with SNPs of the $\beta$-catenin gene. The results of this study showed that $\beta$-catenin is associated with fat accumulation both in vitro and in the human population.
\end{abstract}

Key words : $\beta$-catenin, adipogenesis, SNPs, siRNA, triglyceride

\section{서 론}

비만(obesity)이란 건강에 이상을 초래할 정도의 지방이 체 내에 과잉 축적된 상태를 말한다. 최근, 우리나라를 비롯한 전세계적으로 식습관 및 생활습관 등이 점점 서구화 되면서 비만의 유병률이 크게 증가되고 있다. 비만은 에너지를 저장 하고 대사를 조절하는 지방 조직의 기능을 손상시킴으로써 당뇨, 고혈압, 심혈관계질환 등의 대사성 질환을 유발한다 [7,21]. 따라서, 과도한 지방축적을 예방하고 치료하기 위한 임 상 및 기초 연구가 활발히 이루어지고 있다.

지방세포형성(adipogenesis)은 전지방세포로부터 지방세 포로 분화가 일어나면서 세포형태의 변화, 호르몬 민감성의 변화, 유전자 발현의 변화 그리고 단백질 발현의 변화가 복합 적으로 작용하는 과정이다[19]. 지방세포형성에서 가장 중요 한 핵심조절 인자는 CCAAT/enhancer binding protein $(\mathrm{C} / \mathrm{EBP}) \mathrm{s}$ 와 peroxisome proliferator-activated receptor (PPAR)s로 알려져 있다[18,25,26]. 분화가 시작되면 초기 전사 인자인 $\mathrm{C} / \mathrm{EBP} \beta$ 및 $\mathrm{C} / \mathrm{EBP} \delta$ 가 $\mathrm{C} / \mathrm{EBPa}$ 와 $\mathrm{PPAR} \gamma$ 의 발현량

*Corresponding author

Tel : +82-2-820-5767, Fax : +82-2-813-5387

E-mail : thanks@cau.ac.kr
을 증가시키며 이는 최종적으로 lipoprotein lipase (LPL), adiponectin, leptin, fatty acid binding protein (FABP) 4 와 같은 최종마커(terminal marker)들의 발현을 촉진시킨다[8]. 최근, 이러한 지방세포형성 과정에 wingless-type MMTV integration site $(\mathrm{WNT}) / \beta$-catenin pathway가 연관성이 있음이 보고되었다. WNT/ $\beta$-catenin pathway는 지방세포형성에서 핵심 전사인자들인 $\mathrm{PPAR} \gamma$ 와 $\mathrm{C} / \mathrm{EBPa}$ 를 조절함으로써 지방 세포형성을 저해한다[22,17]. WNT/ $\beta$-catenin pathway에서 frizzled (FZ), low density lipoprotein receptor-related protein (LRP) 수용체에 WNT가 결합하게 되면 disheveled (DVL) 의 활성을 유도하고 glycogen synthase kinase (GSK) 3ß, adenomatous polyposis coli (APC) 및 AXIN 의 복합체의 억제 를 유도한다[5,10]. 그 결과, $\beta$-catenin의 분해가 억제되면서 핵으로의 이동이 증가하게 되고, 이는 T cell factor/Lymphoid enhancer factor (TCF/LEF)와 결합을 통해 $\operatorname{PPAR} \gamma, \mathrm{C} / \mathrm{EBPa}$ 의 발현을 억제시키는 cyclin D1 (CCND1) 등과 같은 다양한 타겟 유전자들의 발현을 촉진시킨다[11,13,14,21,26].

Single Nucleotide Polymorphisms (SNPs)는 단일염기서열 변이를 의미하는 유전적 다형성이다[1,29]. 이는 유전적 다형 성 중에서 가장 많이 존재하는 형태이며 약 300 base pair당 하나의 SNP가 존재하는 것으로 보고되었다[1]. 따라서 인간의 
약 30 억 개의 염기서열에 1,000 만개 정도 존재된다고 추정하 는데 이는 질환에 대한 감수성이나 약제에 대한 부작용 등에 영향을 줄 것으로 생각되고 있다[20]. 환자군과 대조군 사이의 유전자형을 비교하면 특정 유전적 다형성이 질병의 발병여부 와 연관성을 보이는데 이러한 연구를 통하여 질병과 관련된 유전자를 발견할 수 있다[2,24,30,31].

Small interfering RNA (siRNA)는 DNA로부터 단백질의 발현까지의 일련의 과정에서 상보적인 서열과의 결합을 통해 특정RNA를 분해함으로써 특정 유전자로부터 단백질의 합성 을 저해하는데, 최근에는 특정 유전자 및 단백질의 기능을 분 석하는 기술로 많은 연구에 사용되고 있다 $[16,23,28,32]$. 본 연 구에서는 $\beta$-catenin이 지방세포형성 억제에 중요한 역할을 하 고 있음을 증명하기 위해 siRNA기법을 이용한 실험을 수행하 였다. 또한 $\beta$-catenin유전자의 프로모터 영역에 존재하는 단일 염기다형성(SNP)을 분석함으로써 한국인의 $\beta$-catenin유전자 다형성과 혈중지질의 연관성에 대한 연구를 수행하였다.

\section{재료 및 방법}

\section{세포 배양 및 시약}

실험에 사용된 3T3-L1 전지방세포(preadipocyte)는 ATCC (American type culture collection, Manassas, VA, USA)에서 구입하여 Dulbecco's modified Eagle's medium (DMEM)에 $10 \%$ calf serum, $100 \mu \mathrm{g} / \mathrm{ml}$ streptomycin, 100 units $/ \mathrm{ml}$ penicillin과 함께 $37^{\circ} \mathrm{C}, 5 \% \mathrm{CO}_{2}$ 배양기에서 배양하였다. 세포 배 양에 사용된 모든 제품은 Life Technologies Inc. (Gibco, Grand Island, NY, USA)에서 구입하여 사용하였고, 다른 시약 들은 Sigma사(St. Louis, MO, USA)에서 구입하였다.

\section{Adipogenesis 유도}

3T3-L1 세포는phosphate buffered saline (PBS) 용액으로 씻어준 후, $1 \sim 2 \times 10^{5}$ cells $/ \mathrm{ml}$ 를 6 well-plate에서 세포밀도가 $100 \%$ 가 될 때까지 배양하였다. 2 일 후(day0), $10 \%$ fetal bovine serum (FBS)이 첨가된 DMEM에 $1 \mathrm{mg} / \mathrm{ml}$ insulin, $0.25 \mathrm{mM}$ dexamethasone 그리고 $0.5 \mathrm{mM}$ 3-isobutyl-1-methylxanthine 이 처리된 분화 유도 배지(differentiation-induction medium) 로 교체하여 48 시간 처리하였다. 그 후 2 일 간격으로 $10 \% \mathrm{FBS}$ 가 첨가된 새 배지에 $1 \mathrm{mg} / \mathrm{ml}$ insulin이 처리된 분화 유지 배지(differentiation-maintenance medium)로 교체되었다.

\section{si-RNA transfection}

세포밀도가 $100 \%$ 로 배양이 되고 2 일 후, 3T3-L1 세포를 1 시간 동안 serum-free medium에 배양하고 lipofectamine RNAiMAX transfection reagent (Invitrogen, Carlsbad, CA, USA)를 사용하여 $\beta$-catenin, LRP6, DVL2 siRNA 및 control siRNA (Santa Cruz, CA, USA)를 각각 $60 \mathrm{nM}$ 의 농도로 transfection하였다. 6시간 후, 분화 유도 배지로 교환하여 지 방세포의 분화를 유도하였다. 분화 유도 6일에 real-time RT-PCR과 Western blotting에 필요한 total RNA와 단백질 을 추출하였다.

\section{Total RNA 추출}

Total RNA는 acid-phenol 추출법을 이용한 RNeasy kit (Qiagen, Hilden, Germany)를 사용하여 제시된 편람에 따라 분리 정제되었다. 추출된 total RNA는 분광광도계를 이용하 여 optical density (OD) 값을 측정하고 역전사(reverse transcription)반응을 진행할 때까지 $-80^{\circ} \mathrm{C}$ 에 보관하였다.

\section{Real-Time polymerase chain reaction (PCR)}

$1 \mu \mathrm{g}$ 의 total RNA는 cDNA Reverse Transcription Kit (Applied Biosystems, Inc., Foster City, CA, USA)를 이용하여 역전사 하였다. Real-time PCR은 StepOne Real-Time PCR System (Applied Biosystems)장비를 사용하여 진행하였다. $\mathrm{PCR}$ 은 다음의 조성으로 최종 반응 부피를 $20 \mu 1$ 로 동일 샘플 을 triplicate로 준비하여 수행 하였다. TaqMan gene expression master mix, $250 \mathrm{nM}$ 의TaqMan Probe, $2 \mu \mathrm{M}$ 의 각 primer 그리고 $2 \mu \mathrm{l}$ 의 $\mathrm{cDNA}$ 를 적정조성으로 혼합한 반응용액 을 효소를 활성화시키기 위해 $95^{\circ} \mathrm{C}$ 에서 10 분간 반응시킨 후 $95^{\circ} \mathrm{C}$ 에서 15 초, $60^{\circ} \mathrm{C}$ 에서 1 분의 과정으로 40 싸이클을 진행 하였다. Real-Time $\mathrm{PCR}$ 에 사용된 primer는 Applied Biosystems 사의 assay on demand gene expression 제품을 구매하여 사용하였다. Endogenous control는 $18 \mathrm{~S}$ rRNA를 사 용하였다[8]. 각 샘플에 대한 표적유전자의 mRNA수준은 충 분히 발현된 $18 \mathrm{~S} \mathrm{rRNA}$ 에 의해 표준화되었고, 표준화 된 샘플 의 값은 전지방세포(preadipocyte) (day0)의 값을 기준으로 comparative Ct method에 의해 비교 되었다[15].

\section{단백질 추출 및 Western blotting}

분화된 세포들을 cell scraper로 수거한 뒤 ice-cold RIPA buffer를 사용하여 용해시켰다. 용해된 세포들은 $4^{\circ} \mathrm{C}$ 에서 14,000 $\mathrm{rpm}$ 으로 20 분 동안 원심분리 한 후, 단백질이 포함된 상등액을 취하였다. 단백질은 $\mathrm{BCA}$ 를 이용한 protein assay kit (Pierce, Rockford, IL, USA)을 통해 정량 하였다. $50 \mu \mathrm{g}$ 의 단백질을 $10 \%$ SDS-polyacrylamide gel에 전기영동(electrophoresis) 한 후, $150 \mathrm{~mA}$ 로 1 시간 동안 nitrocellulose membrane에 전기영 동 하였다. 이후 membrane을 상온에서 2시간 동안 $\mathrm{PBS}$ 로 만 들어진 $5 \%$ skim milk로 blocking하고 $4{ }^{\circ} \mathrm{C}$ 에서 1:1,000으로 희 석된 1 차 항체를 overnight으로 반응 시켰다. Horseradish peroxidase가 붙어있는 anti-rabbit 2차 항체와 1시간 동안 상 온에서 반응 시킨 후, ECL kit (Pierce, Rockford, IL, USA)를 이용하여 확인하였다. Anti-PPAR $\gamma$, anti- $\beta$-Actin, anti-rabbit 2 차 항체 는 Cell signaling (Beverly, MA, USA), anti-C/EBPa 
는 Santa Cruz Biotechnology (Santa Cruz, CA, USA), anti- $\beta$ catenin은 BD Transduction Laboratories (Lexington, $\mathrm{KY}$, USA)에서 구입하여 사용하였다. Anti- $\beta$-Actin 항체는 각 레인 에 동일 량의 단백질이 load되었는지 확인하기 위하여 endogenous control로 사용되었다.

\section{인간피험자 모집}

연구대상이 되는 인간피험자들은 연세대학교 세브란스 병 원(Seoul, Korea)에서 모집되었으며 연구계획은 상기 병원의 기관윤리위원회로부터 승인되었다. 피험자 가운데 심혈관계 질환 약물이나 고지혈증 약물을 투약 하는 자는 본 연구대상 에서 제외하였다. 본 연구는 서면 동의서를 얻은 총 290 명을 대상으로 하였고, 성비는 전체적으로 남성 152명, 여성 138 명 이었다(Table 1).

\section{SNP 발굴 및 분석}

Haploview 프로그램의 HapMap data release 22 를 사용하 여 아시아 인종(CHB+JPT, 중국인과 일본인)의 SNP와 linkage disequilibrium을 확인하였다. QIAamp® DNA blood mini kit (Qiagen. Hilden, Germany)을 이용하여 대상자의 말초혈 액으로부터 genomic DNA를 추출하였다. 각 $\mathrm{SNP}$ 에 대하여 제작 되어진 primer와 probe를 Applied Biosystems사로부터 구입하여 사용하였다. $20 \mathrm{ng}$ 의 Genomic DNA을 TaqMan® Genotyping Master mix (Applied Biosystems), $900 \mathrm{nM}$ pri$\mathrm{mer}$ 와 $200 \mathrm{nM}$ probe에 잘 혼합하여 최종부피를 $10 \mu \mathrm{l}$ 로 맞춘 후, StepOne Real-Time PCR System (Applied Biosystems) 장 비를 사용하여 Genotyping을 진행하였다. 효소의 활성을 위 하여 $50^{\circ} \mathrm{C}$ 에서 1 분, $95^{\circ} \mathrm{C}$ 에서 10 분 반응 후 $95^{\circ} \mathrm{C}$ 에서 15 초, $60^{\circ} \mathrm{C}$ 에서 1 분의 과정으로 40 싸이클을 진행하였다. 데이터 는 SDS 2.1 software (Applied Biosystems)를 사용하여 분석하 였다[6].

\section{Statistical analysis}

모든 실험결과는 평균(mean)표준오차(S.E)로 나타내었고, SPSS ver. 18.0프로그램(SPSS, Chicago, IL, USA)을 이용하여

Table 1. General characteristics of study subjects

\begin{tabular}{lcc}
\hline Variables & $\mathrm{n}$ & Mean \pm SE \\
\hline Age $(\mathrm{yr})$ & 290 & $54.22 \pm 0.77$ \\
Sex (male:female) & 290 & $152: 138$ \\
Systolic blood pressure $(\mathrm{mmHg})$ & 290 & $120.52 \pm 0.81$ \\
Diastolic blood pressure $(\mathrm{mmHg})$ & 290 & $75.37 \pm 0.63$ \\
Total cholesterol $(\mathrm{mg} / \mathrm{dl})$ & 290 & $184.51 \pm 1.69$ \\
LDL-cholesterol $(\mathrm{mg} / \mathrm{dl})$ & 290 & $115.34 \pm 1.67$ \\
HDL-cholesterol $(\mathrm{mg} / \mathrm{dl})$ & 290 & $54.42 \pm 0.74$ \\
Glucose $(\mathrm{mg} / \mathrm{dl})$ & 290 & $92.13 \pm 0.84$ \\
Triglyceride $(\mathrm{mg} / \mathrm{dl})$ & 290 & $127.26 \pm 4.51$ \\
\hline
\end{tabular}

통계적 유의성을 분석하였다. si-RNA transfection된 세포 군 과 대조군, 두군 사이의 비교에 대한 통계의 유의성은 unpaired t-test에 의해 검증되었다. $\beta$-catenin유전자 다형성에 따른 인체 표현형의 연관성 분석은 피험자들의 연령과 성별을 보정한ANCOVA 분석법에 따라 수행되었다. 통계적 유의성 검정은 $\mathrm{p}$-value $<0.05$ 로 하였다.

\section{결과 및 고찰}

Si-RNA 기법을 이용한 지방축적 관련 유전자후보 도출

본 연구에서는 si-RNA를 이용하여 지방세포 분화와 관련 된 유전자들의 기능을 분석함으로써 지방축적 관련 유전자 후보들을 도출하고자 하였다. si-RNA기법은 double strand RNA가 상보적 $\mathrm{mRNA}$ 를 분해하여 단백질을 합성하는 과정 을 간섭하는 현상이다. 이는 특정 단백질의 발현을 억제하 고 그 기능을 분석하기 위하여 최근에 많은 연구에 사용하 고 있다[16,23,28,32]. 따라서 지방세포형성을 억제한다고 알 려져 있는 WNT/ $\beta$-catenin pathway의 주요 molecule들을 siRNA방법을 사용하여 knock-down 한 후, 3T3-L1 세포가 분화될 때 지방세포형성의 주요 인자들에 미치는 영향을 확 인하고자 하였다.

WNT/ $\beta$-catenin pathway의 주요 인자인 $\beta$-catenin은 지방 세포형성의 주요 인자들인 $\mathrm{PPAR} \gamma$ 와 $\mathrm{CEBPa}$ 의 발현을 저해 하는 지방세포형성 억제조절자(anti-adipogenic regulator)로 알려져 있다[17,22]. siRNA를 통해 $\beta$-catenin을 knock-down 한 후, 세포로부터 mRNA를 분리한 뒤 cDNA를 합성하여 real-time PCR실험을 수행하였다. 그 결과, 지방세포형성의 핵 심인자인PPAR $\gamma, \mathrm{CEBPa}$ 의 mRNA발현들이 증가하는 것을 확인할 수 있었다(Fig. 1B, and 1C). 특히 CEBPa의 mRNA발 현 량이 유의하게 증가하였다. Western blotting을 통해 살펴 본 단백질의 발현양상 또한 $\mathrm{mRNA}$ 와 같이 확연하게 증가함을 확인할 수 있었다(Fig. $1 \mathrm{E}, 1 \mathrm{~F}, 1 \mathrm{H}$, and 11). 이러한 결과는 이미 보고된 바와 같이 $\beta$-catenin이 adipogenesis를 억제하는 기능 을 가짐을 제시한다.

다음으로, WNT/ $\beta$-catenin pathway에 포함된 여러 인자들 중 $\beta$-catenin의 상위에 위치한 인자들이 지방세포형성을 조절 하는지 여부를 살펴보았다. LRP6는 WNT/ $\beta$-catenin pathway에서 $\beta$-catenin의 상위에 위치하여 FZ와 함께 WNT와 결 합하는 것으로 알려져 있다[5]. LRP6 유전자가 결손 된 마우스 의 배아세포에 지방형성을 유도하여 분석한 결과 LRP6가 지 방형성을 억제한다는 사실이 보고된바 있다[11]. 본 연구에서 LRP6를 siRNA로 knock-down한 결과, 지방세포형성의 핵심 인자인 $\mathrm{PPAR} \gamma$ 와 $\mathrm{CEBPa}$ 의 발현이 증가되었으나 유의적 효 과는 보이지 않았다(Fig. 2B, 2C, 2D, 2E, 2F, and 2G). 이러한 결과는 LRP6가 adipogenesis의 조절에 있어서 미약한 영향을 주지만 그 효과가 뚜렷하지 못 함을 제시한다. 

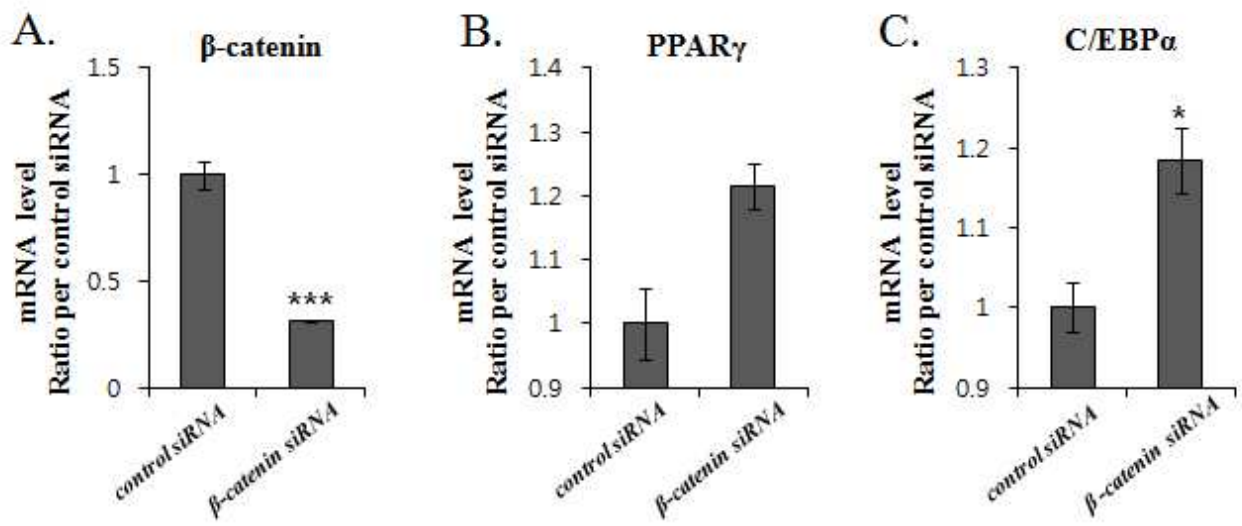

D.

E.

PPAR $\gamma$
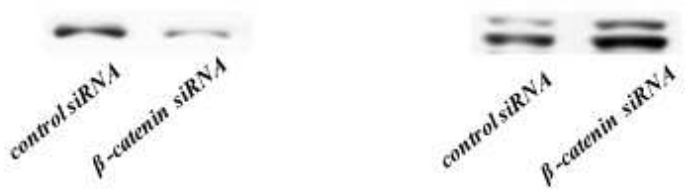

F.

C/EBPa

G.

B-catenin

H.

$\operatorname{PPAR} \gamma$
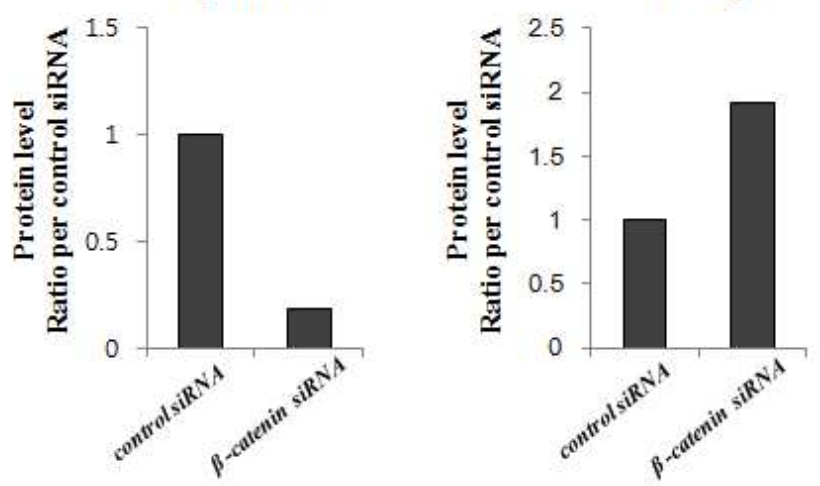

I.

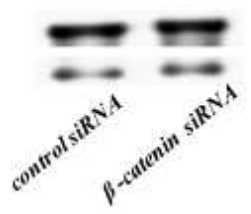

$\mathrm{C} / \mathrm{EBP} \alpha$

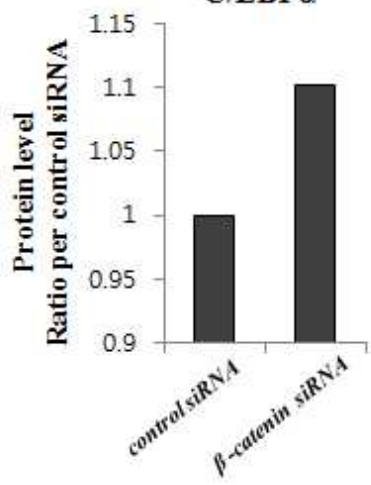

Fig. 1. Effects of $\beta$-catenin siRNA on the expressions of major adipogenic transcription factors in 3T3-L1 cells. The effects of $\beta$-catenin siRNA on the mRNA levels of $\beta$-catenin (A), PPAR $\gamma(\mathrm{B})$, and C/EBPa (C). The results are mean and standard error of triplicate experiments. The effects of $\beta$-catenin siRNA on the protein levels of $\beta$-catenin (D), PPAR $\gamma(\mathrm{E})$, and CEBPa (F). Densitometry data of western blot were also shown $(\mathrm{G}, \mathrm{H}$, and $\mathrm{I}) .{ }^{*} p<0.05,{ }^{* * *} p<0.001$

DVL2는 GSK3ß, AXIN, CK1 복합체를 degradation시킴으 로써 $\beta$-catenin의 안정화를 유도한다고 알려져 있다[22]. 이전 의 연구에서 지방세포형성을 억제하는 물질을 3T3-L1세포에 처리하였을 때 DVL2와 $\beta$-catenin 발현의 증가에 따른 지방세 포형성의 억제 기작을 확인한 바 있다[12]. 그러나siRNA를 이 용한 DVL2의 knock down은 지방세포형성의 주요 인자들의 mRNA 및 단백질의 발현에 거의 영향을 주지 않았다(Fig. 3). siRNA를 이용한 knock-down 실험결과를 종합적으로 분 석하여 보면, $\beta$-catenin, LRP6, DVL2의 순서대로 지방세포 형성의 핵심인자인 $\mathrm{PPAR} \gamma$ 와 $\mathrm{CEBPa}$ 의 발현에 미치는 효 과가 강하게 나타났다. 따라서 가장 뚜렷한 효과를 보인 $\beta$ -catenin이 인체에서의 지방축적과 어떤 연관성을 가지는지 살펴보았다.

한국인의 $\beta$-catenin유전자 다형성과 혈중 지방과의 연관성 특정 유전자의 mRNA 발현 정도는 프로모터에 존재하는 functional SNP에 의해 영향을 받을 수 있다. $\beta$-catenin의 프로 모터에 존재하는 SNP가 혈중 지방과 상관성이 있는지 살펴보 기 위해 한국인 290 명의 유전자형(genotype) 분석을 수행하였 다. 비만의 발생 기전은 여러 유전자의 복합적인 상호작용에 의해서 이루어지며, 식습관과 환경적인 요소 그리고 유전적인 영향에 의해 영향을 받는다[27]. 이러한 비만과 밀접한 임상지 
A.

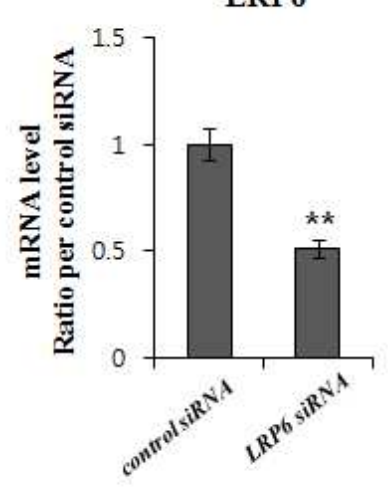

B.

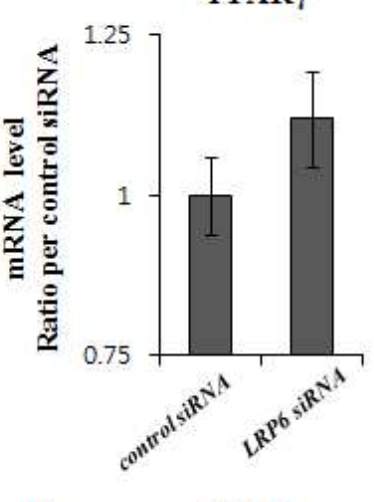

D.

PPAR $\gamma$

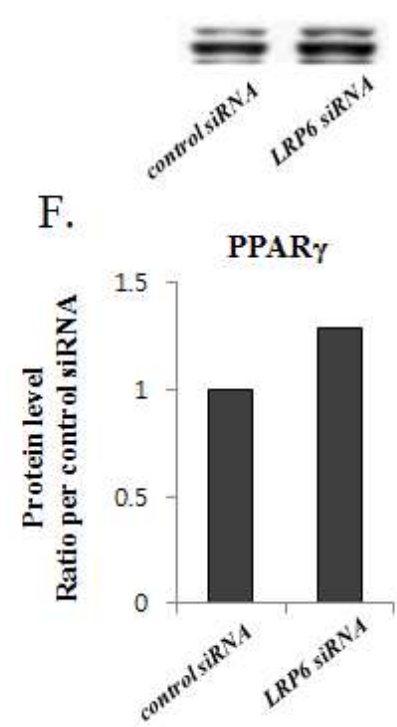

C. $\mathrm{C} / \mathrm{EBP} \alpha$

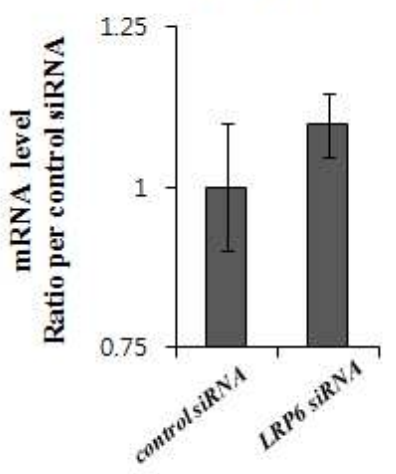

E. $\mathrm{C} / \mathbf{E B P} \alpha$

G.

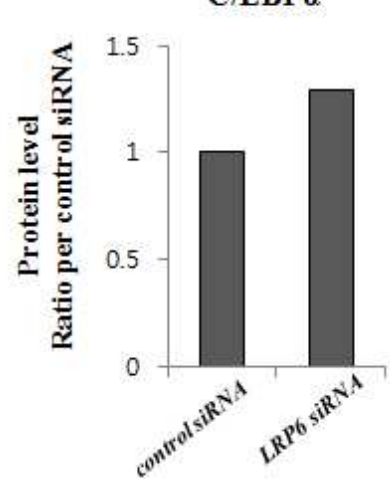

Fig. 2. Effects of LRP6 siRNA on the expressions of major adipogenic transcription factors in 3T3-L1 cells. The effects of LRP6 siRNA on the mRNA levels of LRP6 (A), PPAR $\gamma(\mathrm{B})$, and C/EBPa (C). The results are mean and standard error of triplicate experiments. The effects LRP6 siRNA on the protein levels of PPAR $\gamma$ (D), and CEBPa (E). Densitometry data of western blot were also shown $(\mathrm{F}, \mathrm{G}) .{ }^{* *} p<0.01$

표로서 혈중지질 농도가 대표적인 표지인자로써 사용되어 진 다[3,9].

$\beta$-catenin의 promoter 부위에 위치한 4 개의 SNPs 에 대하여 한국인 290명의 genotype 분석을 실시하였고 전체 대상군 에 서 유전자형의 분포는 Hardy Weinberg equilibrium을 따르는 것으로 확인되었다(Table 2). 한국인의 $\beta$-catenin유전자 단일 염기다형성과 혈중 중성지방 농도와의 연관성을 분석해본 결 과 4개의 tagging SNPs 중에서 transcription (전사) 개시 지점 으로부터 $-10,288$ 위치에 존재하는 $\mathrm{C}$ T polymorphism인 rs7630377 이 유의하게 혈중 중성지방 농도와 특이적으로 연 관성이 있음을 확인할 수 있었다 (Table 3). $-10,288 \mathrm{C}>\mathrm{T}$ 유전자 형에 따른 혈중 중성지방의 평균 농도는 CC 동형집합체 에서
$130.41 \mathrm{mg} / \mathrm{dl}, \mathrm{CT}$ 이형집합체에서 $129.11 \mathrm{mg} / \mathrm{dl}, \mathrm{TT}$ 동형집 합체에서는 $84.86 \mathrm{mg} / \mathrm{dl}$ 으로 측정되어 rare T allele homozygote에서 다른 유전자형에 비해 혈중 중성지방농도가 유의 적으로 낮음이 관찰되었다. 성별과 연령을 보정한 ANCOVA 분석 결과 recessive model에서 p-value가 0.037의 유의한 수 준으로 혈중 중성지방 농도와 연관성이 있음을 확인할 수 있 었다. 동일한 조건과 방법으로 혈중 콜레스테롤 농도와의 연 관성 분석을 해보았으나 유의적으로 영향을 미치는 결과를 확인할 수 없었다(Table 4). 따라서 290명의 한국인을 대상으 로 한 $\beta$-catenin유전자의 SNPs는 비만의 표지인자인 혈중 중 성지방의 농도에 유의적으로 영향을 미치지만 혈중 콜레스테 롤농도 에는 영향을 미치지 못하는 것으로 나타났다. $\beta$ 
A.

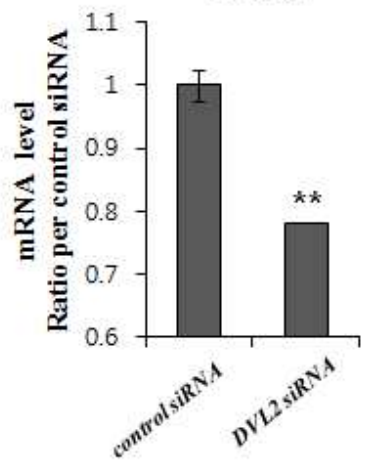

B.

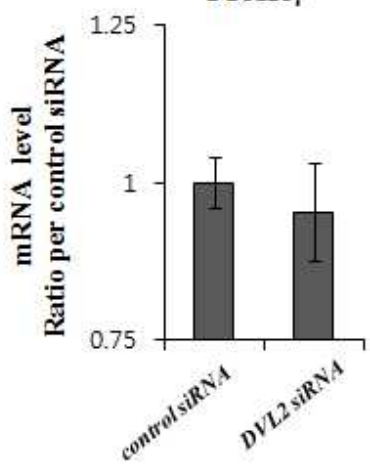

PPAR $\gamma$

D.

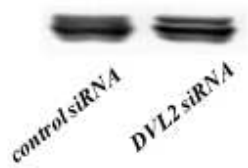

F.

PPAR $\gamma$

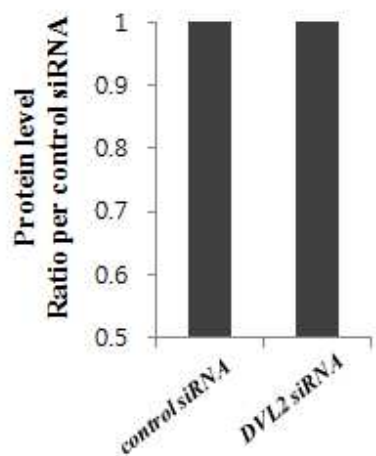

C.

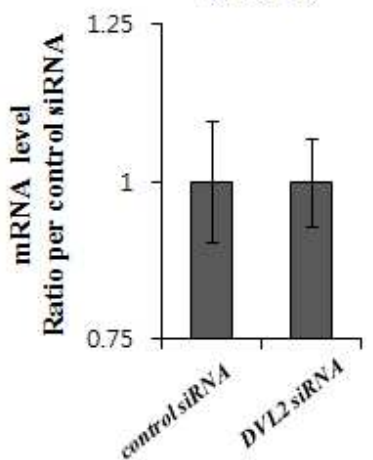

E.

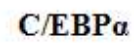

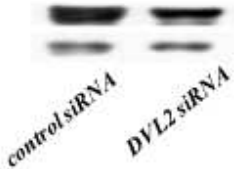

G.

$\mathrm{C} / \mathrm{EBP} \alpha$

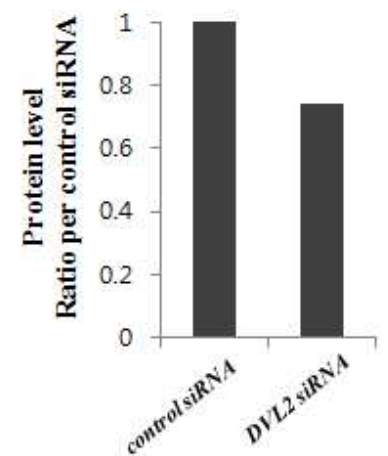

Fig. 3. Effects of DVL2 siRNA on the expressions of major adipogenic transcription factors in 3T3-L1 cells. The effects of DVL2 siRNA on the mRNA levels of DVL2 (A), PPAR $\gamma(\mathrm{B})$, and C/EBPa (C). The results are mean and standard error of triplicate experiments. The effects DVL2 siRNA on the protein levels of PPAR $\gamma$ (D), and CEBPa (E). Densitometry data of western blot were also shown $(\mathrm{F}, \mathrm{G}) .{ }^{* *} p<0.01$

Table 2. SNPs of $\beta$-catenin used for genotyping

\begin{tabular}{lcccccc}
\hline SNP & Position & $\begin{array}{c}\text { Location relative } \\
\text { to transcription } \\
\text { start site }\end{array}$ & $\begin{array}{c}\text { Nucleotide } \\
\text { change }\end{array}$ & $\begin{array}{c}\text { Location relative to } \\
\text { terminus of } \\
\text { chromosome }\end{array}$ & $\begin{array}{c}\text { Minor }^{\mathrm{a}} \\
\text { allele } \\
\text { frequency }\end{array}$ & $\begin{array}{c}\text { HWE }^{\mathrm{b}} \\
\text { p-value }\end{array}$ \\
\hline rs7630377 & Promoter & $-10,288$ & $\mathrm{C}>\mathrm{T}$ & $41,230,654$ & 0.279 & 0.318 \\
rs9859392 & Promoter & $-6,426$ & $\mathrm{C}>\mathrm{G}$ & $41,234,516$ & 0.201 & 0.318 \\
rs9870255 & Promoter & $-4,361$ & $\mathrm{G}>\mathrm{C}$ & $41,236,581$ & 0.199 & 0.318 \\
rs3864004 & Promoter & -765 & $\mathrm{G}>\mathrm{A}$ & $41,240,177$ & 0.201 & 0.318 \\
\hline
\end{tabular}

${ }^{a}$ Minor allele frequencies were obtained from the genotyping of the Korean subjects recruited in this study

${ }^{\mathrm{b}}$ Hardy Weinberg equilibrium

-catenin을 knock out $(\mathrm{KO})$ 한 마우스군 과 대조군 사이의 간 중성지방 농도를 비교한 결과 $\mathrm{KO}$ 마우스 군에서의 간 중성지
방 농도가 대조군 보다 높게 보고된 바 있다[4]. 이상의 결과를 종합하여 볼 때, $\beta$-catenin은 지방세포의 in vitro adipogenesis 
Table 3. Association analyses for SNPs of $\beta$-catenin with serum triglyceride level among Korean subjects

\begin{tabular}{lcrrrcc}
\hline \multirow{2}{*}{ rs number } & \multicolumn{3}{c}{ Triglyceride $(\mathrm{mg} / \mathrm{dl})$} & \multicolumn{2}{c}{$\mathrm{P}^{{ }^{a}}$} \\
\cline { 2 - 7 } & \multicolumn{1}{c}{$\mathrm{CC}^{\mathrm{b}}$} & \multicolumn{1}{c}{$\mathrm{CR}^{\mathrm{b}}$} & $\mathrm{RR}^{\mathrm{b}}$ & Codominant & Dominant & Recessive \\
\hline rs7630377 & $146(130.41 \pm 5.50)$ & $130(129.11 \pm 7.62)$ & $14(84.86 \pm 10.59)$ & 0.111 & 0.481 & 0.037 \\
rs9859392 & $183(129.17 \pm 4.94)$ & $100(126.48 \pm 9.18)$ & $7(103.57 \pm 15.54)$ & 0.656 & 0.656 & 0.381 \\
rs9870255 & $184(128.40 \pm 5.03)$ & $99(123.68 \pm 8.87)$ & $7(133.11 \pm 24.60)$ & 0.872 & 0.658 & 0.864 \\
rs3864004 & $183(129.17 \pm 4.94)$ & $100(126.48 \pm 9.18)$ & $7(103.57 \pm 15.54)$ & 0.656 & 0.656 & 0.381 \\
\hline
\end{tabular}

Data are presented as number of subjects (Mean $\pm \mathrm{SE}$ ), and P-values $<0.05$ are marked by bold characters.

${ }^{a}$ P-values of three alternative models (codominant, dominant and recessive) which were obtained by analyses of covariance adjusted by gender and age.

${ }^{\mathrm{b}} \mathrm{CC}, \mathrm{CR}$, and RR represent homozygotes for common allele, heterozygotes and homozygotes for the rare allele, respectively.

Table 4. Association analyses for SNPs of $\beta$-catenin with serum cholesterol level among Korean subjects.

\begin{tabular}{lcrrrcc}
\hline \multirow{2}{*}{ rs number } & \multicolumn{3}{c}{ cholesterol $(\mathrm{mg} / \mathrm{dl})$} & \multicolumn{3}{c}{$\mathrm{P}^{\text {a }}$} \\
\cline { 2 - 6 } & $\mathrm{CC}^{\mathrm{b}}$ & $\mathrm{CR}^{\mathrm{b}}$ & $\mathrm{RR}^{\mathrm{b}}$ & Codominant $^{\mathrm{b}}$ & Dominant & Recessive \\
\hline rs7630377 & $146(187.91 \pm 2.54)$ & $130(182.99 \pm 2.70)$ & $14(178.29 \pm 6.48)$ & 0.315 & 0.155 & 0.402 \\
rs9859392 & $183(186.62 \pm 2.21)$ & $100(183.78 \pm 3.16)$ & $7(170.00 \pm 11.91)$ & 0.353 & 0.332 & 0.214 \\
rs9870255 & $184(186.50 \pm 2.16)$ & $99(183.67 \pm 3.14)$ & $7(173.00 \pm 10.38)$ & 0.430 & 0.339 & 0.283 \\
rs3864004 & $183(186.62 \pm 2.21)$ & $100(183.78 \pm 3.16)$ & $7(170.00 \pm 11.91)$ & 0.353 & 0.332 & 0.214 \\
\hline
\end{tabular}

Data are presented as number of subjects (Mean \pm SE), and P-values $<0.05$ are marked by bold characters.

${ }^{a}$ P-values of three alternative models (codominant, dominant and recessive) which were obtained by analyses of covariance adjusted by gender and age.

${ }^{\mathrm{b}} \mathrm{CC}, \mathrm{CR}$, and RR represent homozygotes for common allele, heterozygotes and homozygotes for the rare allele, respectively.

뿐만 아니라 인체 내 에서의 혈중 중성지방 농도에서 유의적 인 연관성이 있음이 발견되었다.

\section{감사의 글}

본 연구의 인간 피험자 관련 부분을 도와 주신 연세대학교 보건대학원 지선하 교수님께 감사 드립니다. 본 연구는 2011 년도 정부(교육과학기술부)의 재원으로 한국연구재단의 지원 을 받아 수행되었습니다(No. 2010-0007729).

\section{References}

1. Ahmadian, A., B. Gharizadeh, A. C. Gustafsson, F. Sterky, P. Nyren, M. Uhlen, and J. Lundeberg. 2000. Single-nucleotide polymorphism analysis by pyrosequencing. Anal. Biochem 280, 103-110.

2. Al-Shemari, H., Y. Bosse, T. J. Hudson, M. Cabaluna, M. Duval, M. Lemire, S. Vallee-Smedja, S. Frenkiel, and M. Desrosiers. 2008. Influence of leukotriene gene polymorphisms on chronic rhinosinusitis. BMC Med Genet. 9, 21.

3. Albrink, M. J. and J. W. Meigs. 1965. The relationship between serum triglycerides and skinfold thickness in obese subjects. Ann. N. Y. Acad Sci. 131, 673-683.

4. Behari, J., T. H. Yeh, L. Krauland, W. Otruba, B. Cieply, B. Hauth, U. Apte, T. Wu, R. Evans, and S. P. Monga. 2010. Liver-specific beta-catenin knockout mice exhibit defective bile acid and cholesterol homeostasis and increased susceptibility to diet-induced steatohepatitis. Am J. Pathol. 176, 744-753.

5. Cadigan, K. M. and Y. I. Liu. 2006. Wnt signaling: complexity at the surface. J. Cell Sci. 119, 395-402.

6. Cha, M. H., I. C. Kim, K. S. Kim, B. K. Kang, S. M. Choi, and Y. Yoon. 2007. Association of UCP2 and UCP3 gene polymorphisms with serum high-density lipoprotein cholesterol among Korean women. Metabolism 56, 806-813.

7. Dahlman, I. and P. Arner. 2010. Genetics of adipose tissue biology. Prog. Mol. Biol. Transl. Sci. 94, 39-74.

8. Gustafson, B., and U. Smith. 2006. Cytokines promote Wnt signaling and inflammation and impair the normal differentiation and lipid accumulation in 3T3-L1 preadipocytes. J. Biol. Chem 281, 9507-9516.

9. Hollister, L. E., J. E. Overall, and H. L. Snow. 1967. Relationship of obesity to serum triglyceride, cholesterol, and uric acid, and to plasma-glucose levels. Am J. Clin. Nutr. 20, 777-782.

10. Huelsken, J. and J. Behrens. 2002. The Wnt signalling pathway. J. Cell Sci. 115, 3977-3978.

11. Kawai, M., S. Mushiake, K. Bessho, M. Murakami, N. Namba, C. Kokubu, T. Michigami, and K. Ozono. 2007. Wnt/Lrp/beta-catenin signaling suppresses adipogenesis by inhibiting mutual activation of PPARgamma and C/EBPalpha. Biochem Biophys. Res. Commun. 363, 276-282.

12. Lee, H., S. Bae, K. Kim, W. Kim, S. I. Chung, and Y. Yoon. 2010. Beta-Catenin mediates the anti-adipogenic effect of baicalin. Biochem Biophys. Res. Commun. 398, 741-746. 
13. Lee, H., R. Kang, S. Bae, and Y. Yoon. 2011. AICAR, an activator of AMPK, inhibits adipogenesis via the WNT/beta-catenin pathway in 3T3-L1 adipocytes. Int. J. Mol. Med 28, 65-71.

14. Liu, J. and S. R. Farmer. 2004. Regulating the balance between peroxisome proliferator-activated receptor gamma and beta-catenin signaling during adipogenesis. A glycogen synthase kinase 3beta phosphorylation-defective mutant of beta-catenin inhibits expression of a subset of adipogenic genes. J. Biol. Chem 279, 45020-45027.

15. Livak, K. J. and T. D. Schmittgen. 2001. Analysis of relative gene expression data using real-time quantitative PCR and the 2(-Delta Delta C(T)) Method. Methods 25, 402-408.

16. Ma, X., X. Ren, P. Han, S. Hu, J. Wang, and J. Yin. 2010. SiRNA against Fabp5 induces 3T3-L1 cells apoptosis during adipocytic induction. Mol. Biol. Rep. 37, 4003-4011.

17. Moldes, M., Y. Zuo, R. F. Morrison, D. Silva, B. H. Park, J. Liu, and S. R. Farmer. 2003. Peroxisome-proliferator-activated receptor gamma suppresses Wnt/beta-catenin signalling during adipogenesis. Biochem J. 376, 607-613.

18. Morrison, R. F. and S. R. Farmer. 1999. Role of PPARgamma in regulating a cascade expression of cyclin-dependent kinase inhibitors, p18(INK4c) and p21(Waf1/Cip1), during adipogenesis. J. Biol. Chem 274, 17088-17097.

19. Ntambi, J. M. and K. Young-Cheul. 2000. Adipocyte differentiation and gene expression. J. Nutr. 130, 3122S-3126S.

20. Pereira, D. S., D. M. Garcia, F. M. Narciso, M. L. Santos, J. M. Dias, B. Z, Queiroz, E. R. Souza, O. T. Nobrega, and L. S. Pereira. 2011. Effects of $174 \mathrm{G} / \mathrm{C}$ polymorphism in the promoter region of the interleukin- 6 gene on plasma IL-6 levels and muscle strength in elderly women. Braz. J. Med Biol. Res. 44, 123-129.

21. Qin, L., Y. Chen, Y. Niu, W. Chen, Q. Wang, S. Xiao, A. Li, Y. Xie, J. Li, X. Zhao, Z. He, and D. Mo. 2010. A deep investigation into the adipogenesis mechanism: profile of microRNAs regulating adipogenesis by modulating the canonical Wnt/beta-catenin signaling pathway. BMC Genomics 11, 320 .

22. Ross, S. E., N. Hemati, K. A. Longo, C. N. Bennett, P. C. Lucas, R. L. Erickson, and O. A. MacDougald. 2000. Inhibition of adipogenesis by Wnt signaling. Science 289, 950-953.

23. Sakurai, K., M. Amarzguioui, D. H. Kim, J. Alluin, B. Heale, M. S. Song, A. Gatignol, M. A. Behlke, and J. J. Rossi. 2011.
A role for human Dicer in pre-RISC loading of siRNAs. Nucleic Acids Res. 39, 1510-1525.

24. Salpea, K. D., D. R. Gable, J. A. Cooper, J. W. Stephens, S. J. Hurel, H. A. Ireland, M. D. Feher, I. F. Godsland, and S. E. Humphries. 2009. The effect of WNT5B IVS3C $>$ G on the susceptibility to type 2 diabetes in UK Caucasian subjects. Nutr. Metab. Cardiovasc. Dis. 19, 140-145.

25. Shao, D. and M. A. Lazar. 1997. Peroxisome proliferator activated receptor gamma, CCAAT/enhancer-binding protein alpha, and cell cycle status regulate the commitment to adipocyte differentiation. J. Biol. Chem. 272, 21473-21478.

26. Van Tienen, F. H., H. Laeremans, C. J. Van der Kallen, and H. J. Smeets. 2009. Wnt5b stimulates adipogenesis by activating PPARgamma, and inhibiting the beta-catenin dependent Wnt signaling pathway together with Wnt5a. Biochem Biophys. Res. Commun. 387, 207-211.

27. Vermeulen, A. 1993. Metabolic effects of obesity in men. Verh K. Acad Geneeskd Belg. 55, 383-393.

28. Wall, N. R., and Y. Shi. 2003. Small RNA: can RNA interference be exploited for therapy? Lancet 362, 1401-1403.

29. Wang, D. G., J. B. Fan, C. J. Siao, A. Berno, P. Young, R. Sapolsky, G. Ghandour, N. Perkins, E. Winchester, J. Spencer, L. Kruglyak, L. Stein, L. Hsie, T. Topaloglou, E. Hubbell, E. Robinson, M. Mittmann, M. S. Morris, N. Shen, D. Kilburn, J. Rioux, C. Nusbaum, S. Rozen, T. J. Hudson, R. Lipshutz, M. Chee, and E. S. Lander. 1998. Large-scale identification, mapping, and genotyping of single-nucleotide polymorphisms in the human genome. Science 280, 1077-1082.

30. Wang, K., W. D. Li, C. K. Zhang, Z. Wang, J. T. Glessner, S. F. Grant, H. Zhao, H. Hakonarson, and R. A. Price. 2011. A genome-wide association study on obesity and obesity-related traits. PLoS One 6, e18939.

31. Yamaguchi, Y., M. Moritani, T. Tanahashi, D. Osabe, K. Nomura, Y. Fujita, P. Keshavarz, K. Kunika, N. Nakamura, T. Yoshikawa, E. Ichiishi, H. Shiota, N. Yasui, H. Inoue, and M. Itakura. 2008. Lack of association of genetic variation in chromosome region 15q14-22.1 with type 2 diabetes in a Japanese population. BMC Med Genet. 9, 22.

32. Zuckerman, J. E., T. Hsueh, R. C. Koya, M. E. Davis, and A. Ribas. 2011. siRNA knockdown of ribonucleotide reductase inhibits melanoma cell line proliferation alone or synergistically with temozolomide. J. Invest. Dermatol. 131, 453-460. 
초록 : $\beta$-catenin 유전자의 3T3-L1 지방세포 및 인체에서의 지방축적 연관성 연구

배성민 ${ }^{1} \cdot$ 이해용 ${ }^{1}$ 채수안 ${ }^{2} \cdot$ 오동진 ${ }^{3} \cdot$ 박석원 $^{4} \cdot$ 윤유식 ${ }^{1}{ }^{*}$

(1중앙대학교 의과대학 미생물학교실, ${ }^{2}$ 소아과학교실, ${ }^{3}$ 내과학교실, ${ }^{4}$ 방사선종양학과)

비만은 중성지방이 체내에 과잉으로 축적되어 지방 본래의 에너지 저장과 대사조절의 기능을 정상적으로 하지 못하는 상태를 말한다. 본 연구진은 siRNA 방법을 이용하여 Wingless-type MMTV integration site (WNT)/ $\beta$ -catenin pathway에 의한 지방축적 조절에서 중요한 역할을 하는 유전자를 확인하고자 하였다. WNT/ $\beta$-catenin pathway에 속한 유전자 중 $\beta$-catenin을 siRNA기법을 통하여 knock down 한 후 adipogenesis의 핵심 조절자인 peroxisome proliferator-activated receptor (PPAR) $\gamma, \mathrm{CCAAT} /$ enhancer binding protein (C/EBP) $a$ 의 mRNA와 단백질 발현 변화를 확인해 보았다. 그 결과 $\beta$-catenin유전자의 knock down에 의하여 $\operatorname{PPAR} \gamma, \mathrm{CEBPa}$ 의 유전자 및 단백질 발현이 유의하게 증가함을 확인하였다. WNT/ $\beta$-catenin pathway에서 $\beta$-catenin의 상위 조절자인 LRP6와 DVL2의 knock down에 의한 adipogenesis 조절 유무를 분석하였으나 유의적인 영향을 미치지 못하는 것으로 발견되었다. 이는 $\beta$-catenin이 상위 조절자들의 영향을 받기 보다는 독립적인 기작으로 $\mathrm{PPAR} \gamma, \mathrm{CEBPa}$ 의 mRNA, 단백질 발현의 조절함으로써 adipogenesis의 negative regulator의 기능을 하는 것으로 판단된다. 또 한 290명의 한국인을 대상으로 비만의 대표적인 표지인자인 혈중 중성지방 농도와 혈중 콜레스테롤 농도에 대한 $\beta$-catenin 유전자의 단일염기다형성(SNP)과의 연관성을 통계 분석해보았다. 그 결과 프로모터 부분에 위치한 4 종 류의 SNP 중에서 transcription개시 지점으로부터 -10,288위치에 존재하는 C>T polymorphism인 rs7630377이 유 의하게 혈중 중성지방 농도와 연관성이 있음을 확인할 수 있었다. 본 연구의 결과는 $\beta$-catenin이 세포 수준에서 뿐 아니라 인체에서도 지방축적에 유의적인 영향을 미치고 있음을 제시하고 있다. 